\title{
Air quality management in Auckland, New Zealand
}

\author{
J. K. Symons, N. S. Leksmono, E. T. Hayes, T. J. Chatterton \\ \& J. W. S. Longhurst \\ Air Quality Management Resource Centre, \\ University of the West of England, Bristol, UK
}

\begin{abstract}
Air quality in New Zealand is perceived by many to be very good. This is facilitated by low population density, geographical isolation and a maritime climate. The climate and weather of New Zealand is also affected by large scale wind systems which promote westerly winds and aid dispersion.

Despite favourable conditions, air pollution is a problem in many urban centres in New Zealand. Although industrial emissions contribute to pollution, emissions from domestic and traffic sources are significant. Outdoor burning and domestic fires are common, and are a major source of air pollutants and complaints. National Environmental Standards for Ambient Air Quality were introduced in 2004 but these are unlikely to be achieved in a number of locations including Auckland, New Zealand's largest city, where traffic emissions are the major source of air pollution.

Auckland's population is 1.3 million people (almost one third of the national total). The city covers an area approximately equal in size to London. Poorly developed public transport services and urban sprawl have resulted in reliance on private vehicles, and ownership rates in New Zealand are among the highest in the world. In conjunction with an aged vehicle fleet and severe traffic congestion, the resulting air pollution has become a significant issue in Auckland.

This paper considers the process of air quality management in New Zealand, illustrated by the particular problems systemic to Auckland. Policy responses include a Regional Land Transport Strategy with health protection as a key objective. However, it is far from certain whether these will successfully deliver cleaner air, and further national guidance and additional transport focussed regulations may be needed to achieve the air quality improvements in Auckland necessary to meet the national Standards.
\end{abstract}

Keywords: air quality management, traffic, Auckland, New Zealand. 


\section{Introduction}

New Zealand is an island nation in the South West Pacific. It is relatively isolated, with Australia as its nearest large neighbour located approximately $2000 \mathrm{~km}$ west of New Zealand, across the Tasman Sea. The country has a temperate, maritime climate, which is subject to the large scale wind systems dominating the mid latitudes. The 'roaring forties' winds, an interaction between Antarctic and tropical weather systems, ensure predominant westerly winds affect the length of the country, aiding dispersion in most locations.

New Zealand has a land area of $268,021 \mathrm{~km}^{2}$ (slightly larger than $241,590 \mathrm{~km}^{2}$ - the area of the United Kingdom (UK)) and a population of approximately 4.1 million people [1], of which $80 \%$ live in cities [2]. The largest of these cities is Auckland, situated on an isthmus in the northern part of the North Island (Figure 1).

The Auckland region is home to approximately 1.3 million people [1]. The urban environment of the region covers about one tenth of the land area, the remainder of which is made up of farmland, coast, and forests.

The population density of the region is 81 people $/ \mathrm{km}^{2}$, much higher than the New Zealand national average of 15 people $/ \mathrm{km}^{2}$ [1], but still relatively low compared to that of Greater London (approximately 4750 people $/ \mathrm{km}^{2}$ ) or the UK (250 people $/ \mathrm{km}^{2}$ ). Auckland's intense population growth since European settlement in the $1840 \mathrm{~s}$, and particularly since the rise in popularity of the motorcar, has resulted in rapid expansion of the urban area through urban sprawl. Relatively large residential properties and suburban style housing dominate the urban landscape, pushing the urban/suburban boundary and commuting distances further from the centre, and making the provision of efficient public transport increasingly difficult. Despite Auckland's windy coastal environment, transport and domestic emissions cause significant air quality problems across the region: ambient concentrations of nitrogen dioxide and $\mathrm{PM}_{10}$ frequently exceed world health organisation guidelines and national standards.

This paper provides a review of air quality management in New Zealand with comparisons to air quality management processes in the UK and Europe with reference to the specific problems experienced in Auckland.

\section{Legislative background}

The first documented instances of air pollution in New Zealand date back to the 1890s [3]. By the 1950s air quality issues were identified in the city centres of Christchurch and Auckland, relating to odour, industrial emissions, smoky domestic fires and traffic. The Clean Air Act of 1972 authorised the regulation of operations at industrial sites to ensure emissions were minimised by the Best Practicable Means (BPM), a concept first introduced in the UK Alkali Act (1874). The Clean Air Act was administered by the Department of Health, who monitored and investigated emissions from large industries. City and District Councils were responsible for regulation of smaller industries with discharges to air. 


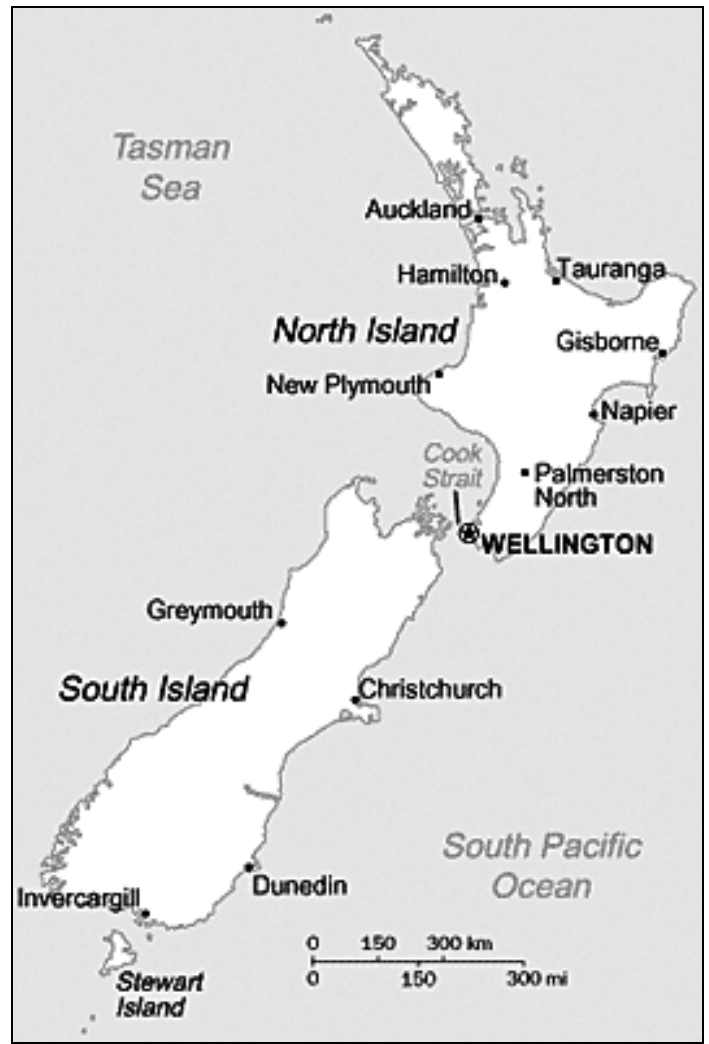

Figure 1: $\quad$ Map of New Zealand [4].

\subsection{The Resource Management Act (1991)}

In 1991, the Resource Management Act (RMA) was introduced; the first legislation for the integrated sustainable management of all New Zealand's natural and cultural resources, and built environment. The RMA is a framework for integrating and rationalising environmental management. It superseded 59 statutes and modified 50 regulations [5]. The RMA turned the focus of environmental management away from the potentially polluting activities, and towards the management of the effects of those activities on the surrounding environment. The role of central Government is to set policy on matters of national significance and monitor implementation of the RMA. Air quality management is carried out by the 12 Regional Councils (and the four Unitary Councils who fulfil the combined responsibilities of Regional and District/City Councils). Air discharge consents are granted by the councils based on compliance of the process with the rules of the respective Regional Plan, and an assessment of environmental effects which must accompany a consent application demonstrating that the application meets the overriding objective of the RMA to "avoid, remedy or mitigate the effects of activities on the 
environment" [6] In addition to the administration of air discharge consents, Regional Councils are required to monitor the state of the environment, consent compliance, Regional Plan effectiveness, and the outcome of transfers of power (to District Councils). The move of air quality management from central to local government is based on the assumption that governing bodies closest to resources are the most appropriate to govern the use of them [5], and is similar to the approach taken in the UK [7]. In this manner, the specific needs and values of local communities and, in New Zealand, of the native Mäori peoples, are better identified.

Until the adoption of the RMA, air quality monitoring in New Zealand was limited and disorganised. Due to relatively few large industries, and low population density, air pollution was not perceived to be a problem. The advent of the RMA and the requirement for Regional Councils to report on the state of the environment, identified that air quality in New Zealand may not be as good as expected, and that some areas exist where concentrations give reason for concern. To this end, the National Environmental Standards Relating to Certain Air Pollutants, Dioxins, and Other Toxics (NES) were introduced in New Zealand in October 2004 [8].

\subsection{National Environmental Standards relating to certain air pollutants, dioxins, and other toxics (2004)}

The NES are mandatory standards aimed at protecting air quality which apply nationally. The NES include regulations regarding ambient air quality concentrations (Table 1) and also rules for activities producing discharges to air, such as the burning of oil, operation of incinerators and the use of solid fuel domestic heating appliances. Following the adoption of this legislation, by $1^{\text {st }}$ September 2005 Regional Councils and Unitary Authorities had identified 38 areas where exceedences of the standard were considered likely [9]. These are designated as 'airsheds'.

Table 1: $\quad$ National Environmental Standards [8].

\begin{tabular}{|c|c|c|c|c|}
\hline \multirow[t]{2}{*}{ POLLUTANT } & \multirow[t]{2}{*}{$\begin{array}{l}\text { STANDAR } \\
\text { D }\end{array}$} & \multirow[t]{2}{*}{ TIME AVERAGE } & \multicolumn{2}{|c|}{$\begin{array}{c}\text { ALLOWABLE } \\
\text { EXCEEDENCES PER } \\
\text { YEAR }\end{array}$} \\
\hline & & & $\mathbf{N Z}$ & $\mathbf{U K} / \mathbf{E U}$ \\
\hline $\begin{array}{c}\text { Carbon monoxide } \\
\text { (CO) }\end{array}$ & $10 \mathrm{mg} / \mathrm{m}^{3}$ & $\begin{array}{c}\text { 8-hours } \\
\text { (running mean) }\end{array}$ & 1 & - \\
\hline $\begin{array}{c}\text { Nitrogen dioxide } \\
\left(\mathrm{NO}_{2}\right)\end{array}$ & $200 \mu \mathrm{g} / \mathrm{m}^{3}$ & 1-hour mean & 9 & 18 \\
\hline Ozone $\left(\mathrm{O}_{3}\right)$ & $150 \mu \mathrm{g} / \mathrm{m}^{3}$ & 1-hour mean & $\begin{array}{c}0 \text { - Must not } \\
\text { exceed }\end{array}$ & NA \\
\hline $\begin{array}{c}\text { Fine particles } \\
\left(\mathrm{PM}_{10}\right)\end{array}$ & $50 \mu \mathrm{g} / \mathrm{m}^{3}$ & 24-hour mean & 1 & 35 \\
\hline $\begin{array}{c}\text { Sulphur dioxide } \\
\left(\mathrm{SO}_{2}\right)\end{array}$ & $\begin{array}{l}350 \mu \mathrm{g} / \mathrm{m}^{3} \\
570 \mu \mathrm{g} / \mathrm{m}^{3}\end{array}$ & $\begin{array}{l}\text { 1-hour mean } \\
1 \text {-hour mean }\end{array}$ & $\begin{array}{l}9 \\
0\end{array}$ & $\begin{array}{c}24 \\
-\end{array}$ \\
\hline
\end{tabular}


Regional Councils in New Zealand are encouraged to develop airshed action plans to move towards compliance with the fine particle standard by 2013, in relation to $\mathrm{PM}_{10}$ which is the standard for which breaches are most likely. Airshed action plans may also be prepared for areas that do not breach the ambient standard - to ensure that this remains the case. An airshed action plan is not a legal requirement of the regulations of the NES, but a strategy to achieve compliance. This is similar to the situation in the UK where local authorities must declare Air Quality Management Areas (AQMA) in locations where pollutant concentrations exceed the air quality objectives. Within 18 months of this declaration, however an Action Plan must be completed. The Action Plan should include details of what measures local authorities are going to introduce, and when, and how these will improve air quality towards meeting the air quality objectives.

The regulations in the NES place different constraints upon the resource consent process depending on the contaminant of concern in the application [9]. Regional Councils are required to publicly report any breaches of the standards on a monthly basis until the standard is no longer breached. With respect to the $\mathrm{PM}_{10}$ standard, Regional Councils are required to produce a plan in the form of a 'straight line path' or 'curved line path' from the representative $\mathrm{PM}_{10}$ concentration on $1^{\text {st }}$ September 2005 to the standard concentration that should be met by the date included in the regulation $-1^{\text {st }}$ September 2013 . If there is a breach of the $\mathrm{PM}_{10}$ standard measured within the airshed subsequent to $1^{\text {st }}$ September 2005, the Regional Council must not give consent for further significant discharges of fine particles to air if the discharges are likely to cause concentrations within the airshed to be above the straight line path or curved line path to meeting the standard [8]. Similarly, applications for consent to discharge other contaminants to air, such as carbon monoxide $(\mathrm{CO})$, sulphur dioxide $\left(\mathrm{SO}_{2}\right)$, nitrogen oxides $\left(\mathrm{NO}_{\mathrm{x}}\right)$ and volatile organic compounds (VOC) are also affected by the NES, and the quality of the air within the airshed directly affects the ability for industry to obtain new or renewed consents to operate within the airshed.

\section{Air quality in Auckland}

Auckland is New Zealand's largest, most populated city. Although industry is more intensive in Auckland than in any other region in New Zealand, it is transport and domestic emissions that dominate the quality of the air. The Auckland Air Emissions Inventory 2004 estimates [10] show that within the Auckland Region, transport is the principal contributor to ambient concentrations of six pollutants considered in the inventory (Table 2).

Auckland Regional Council operates an extensive ambient monitoring network, including continuous carbon monoxide $(\mathrm{CO})$, sulphur dioxide $\left(\mathrm{SO}_{2}\right)$, nitrogen oxides $\left(\mathrm{NO}_{\mathrm{x}}\right)$, ozone $\left(\mathrm{O}_{3}\right)$, and beta attenuation monitor particulate $\left(\mathrm{PM}_{10}\right.$ and $\left.\mathrm{PM}_{2.5}\right)$ analysers. 24-hour medium volume gravimetric $\mathrm{PM}_{10}$ and $\mathrm{PM}_{2.5}$ monitors are also operated in a number of locations across the region, as well as numerous seasonal studies. This network has been developed over recent 
years, and Auckland Regional Council has an increasing understanding of air quality across the region [11].

As required by the NES, due to breaches of the standards, Auckland Regional Council has declared one large airshed covering the entire metropolitan area of the region. Within this airshed, monitoring must be carried out using approved reference methods, in locations identified as potentially worst-scenario locations, in terms of exposure, and intensity or duration of pollution event.

Table 2: $\quad$ Greater London and Auckland Region Emissions [10, 12].

\begin{tabular}{|c|c|c|c|c|c|c|}
\hline \multirow{2}{*}{$\begin{array}{l}\text { POLLUTAN } \\
\text { T }\end{array}$} & \multicolumn{2}{|c|}{$\begin{array}{l}\text { TOTAL ANNUAL } \\
\text { EMISSIONS (T/YR) }\end{array}$} & \multicolumn{4}{|c|}{$\begin{array}{l}\text { AUCKLAND CONTRIBUTIONS } \\
\text { EMISSIONS FROM SOURCE }\end{array}$} \\
\hline & $\begin{array}{l}\text { Greater } \\
\text { London }\end{array}$ & $\begin{array}{l}\text { Auckland } \\
\text { Region }\end{array}$ & Transport $^{\#}$ & Domestic & Industrial & Biogenic \\
\hline $\mathrm{PM}_{10}{ }^{*}$ & 3,820 & 5,900 & $47 \%$ & $39 \%$ & $14 \%$ & \\
\hline $\mathrm{NO}_{\mathrm{x}}$ & 60,640 & 35,000 & $83 \%$ & $1 \%$ & $13 \%$ & $3 \%$ \\
\hline $\mathrm{CO}$ & 111,645 & 171,200 & $85 \%$ & $13 \%$ & $2 \%$ & \\
\hline VOC & 71,803 & 64,200 & $52 \%$ & $9 \%$ & $26 \%$ & $13 \%$ \\
\hline $\mathrm{SO}_{2}$ & 1,913 & 4,200 & $65 \%$ & $3 \%$ & $32 \%$ & \\
\hline $\mathrm{CO}_{2}$ & $15,497,385$ & $8,930,000$ & $48 \%$ & $6 \%$ & $46 \%$ & \\
\hline
\end{tabular}

* secondary particulates, sea salt, re-suspended dust not included in estimate

\# motor vehicles are responsible for $91 \%$ of transport sector emissions

\section{1 $\mathrm{PM}_{10}$ and $\mathrm{NO}_{2}$}

$\mathrm{PM}_{10}$ and $\mathrm{NO}_{2}$ concentrations in the Auckland Region currently exceed health guidelines and NES standards. Seasonal variation skews the relative concentration of the sources of $\mathrm{PM}_{10}$, and illustrates the significance of particulate from domestic emissions (mainly domestic heating; Figure 2). 63\% of households in the region burn solid fuel (mainly wood) for domestic heating [13].

A substantial proportion of domestic particulate emissions are from outdoor burning. Cultural cooking rights of Mäori and Pacific Islanders are maintained throughout the region, and the resulting outdoor, backyard fires are a significant source of particulates and air quality nuisance complaints.

Although domestic emissions in winter are substantially larger than the contribution of traffic emissions of $\mathrm{PM}_{10}$ in the region, traffic emissions (including exhaust emissions and tyre and brake wear) are a significant source of $\mathrm{PM}_{10}$. As a product of combustion, the majority of oxides of nitrogen emissions in the Auckland Region are from traffic and industrial sources, as shown in Table 2.

The inventory for the Auckland region indicates that strategies which target emissions from transport and domestic heating will have the greatest impact on improving air quality. 


\section{Management of target emissions in Auckland}

\subsection{Domestic heating}

The NES includes regulations covering design and thermal efficiency standards of 'woodburners'. The NES refers to woodburners specifically, therefore, other domestic heating units which burn solid fuel and are not called woodburners are not included under this regulation. Coal ranges and open fires are considered the most polluting types of solid fuel domestic heaters, yet are not regulated in this legislation.

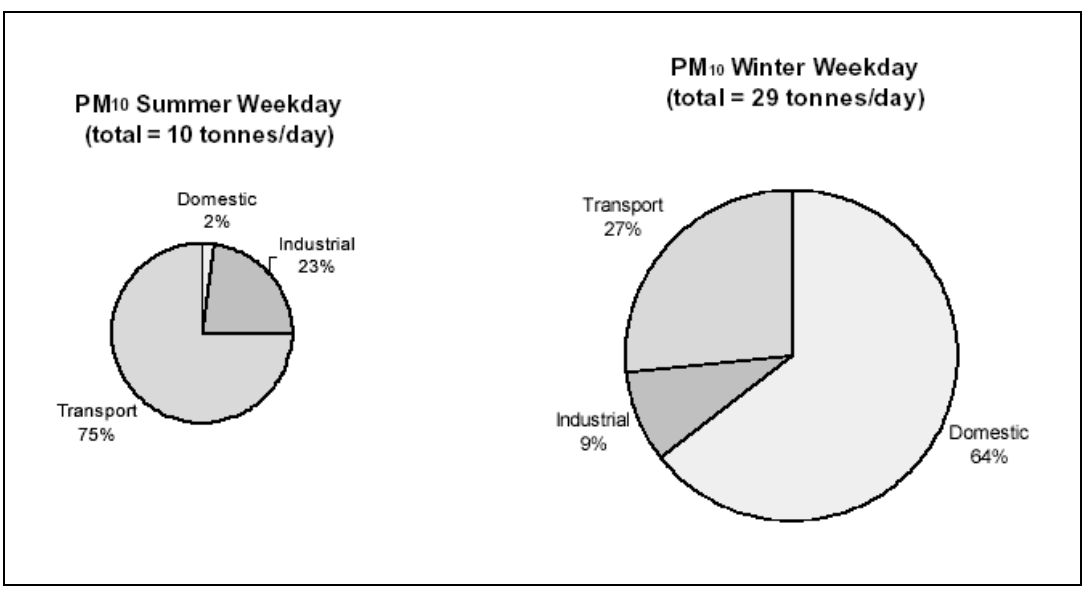

Figure 2: $\quad$ Auckland $\mathrm{PM}_{10}$ emissions source contributions [10].

The Auckland Regional Plan includes similar rules regarding the efficiency standards required for new solid fuel domestic heating units installed in homes within the region, and policies regarding the encouragement of clean burning domestic heating methods. However, under the RMA, regulation is carried out on the basis of the effects of the activities, rather than the activity itself. Although there has been some success in regulation of domestic heating appliances in other parts of New Zealand, there is currently no adequate system or legislation in place to regulate the models of solid fuel domestic heaters being installed and operated in Auckland homes.

By comparison, domestic emissions in the UK are managed in a different way. The severe smog events in the 1930s and the catastrophic London Smog of 1952 played an important part in the development of the Clean Air Act (1956) which attempted to control domestic and industrial emissions. The Clean Air Act allowed local authorities to designate 'smoke control areas' where grants to update domestic heating were introduced, and only smokeless fuel could be burned. These areas are still maintained, and local authorities in the UK continue to identify and address potential areas of concentrated domestic emissions via the Local Air Quality Management 'Review and Assessment' process. 


\subsection{Transport emissions}

New Zealand has one of the highest car ownership rates in the world (79 licensed vehicles per one hundred population). There are almost 1 million licensed vehicles in the Auckland Region [14], and approximately 17\% of households have access to three or more motor vehicles [15] (compared to only 5\% of households in the UK) [16]. The New Zealand traffic fleet age is on average 12 years old [17], equivalent to the technology level of the Euro I vehicle standard, whereas the UK vehicle fleet has an average age of approximately half this [18], equivalent to a Euro II vehicle.

There is no vehicle manufacturing industry in New Zealand and all vehicles are imported. Vehicles are not subject to emissions testing on import into the country, or during regular mandatory warrant of fitness checks. At the time of manufacture, vehicles must have been capable of meeting certain standards. Following a detailed study regarding implementation of emission testing into routine vehicle fitness checks, the Ministry of Transport recently decided that emissions testing will not be introduced in the near future to regulate vehicle emissions in New Zealand [19]. Alternatively, the 'visible smoke test' will be introduced to the warrant of fitness check. The visible smoke test entails a visual assessment of emissions from a vehicle under set conditions. If smoke is emitted for more than five seconds, the vehicle will fail the test until it is tuned or repaired. In addition to the visual smoke test, a prohibition was introduced on the removal of, or tampering with, emission control equipment installed on vehicles, something frequently done in New Zealand in an effort by owners to increase vehicle 'performance'.

The majority of fuel used in New Zealand is produced at a refinery in the North Island subject to the standards imposed by the Ministry of Economic Development. Poor fuel standards in New Zealand have also contributed to the extent of traffic emissions in the country. Benzene and sulphur concentrations in diesel and petrol are high and New Zealand is at least two years behind the EU directives in terms of fuel quality and decreases in pollutant concentration.

Regional councils are required to develop regional land transport strategies that guide the decision making of local authorities. The Auckland Regional Transport Strategy includes the five objectives from the New Zealand Transport Strategy; Assisting Safety; Ensuring Environmental Sustainability; Assisting Economic Development; Improving Access and Mobility; and Protecting and Promoting Public Health, as well as two additional objectives focused on aims specific to Auckland's regional growth and economy. It states that further work beyond the objectives of the strategy will be needed to achieve regionally significant improvements with respect to environmental outcomes [20]. However, the strategy provides an increase in spending on public transport and travel demand management, with a focus on increasing public transport availability in areas identified as regional growth centres. Although positive steps are planned to manage traffic more effectively, as roughly $60-80 \%$ of emissions in Auckland come from vehicles (depending on pollutant) [20] it is not certain that this strategy will be sufficient to improve pollution to the necessary levels. 
Although the land area of the UK is similar to that of New Zealand, it has a significantly higher population of approximately 60 million, and over 32 million road vehicles. The UK has experienced a considerable increase in vehicle usage (vehicle kilometres rose 79\% between 1980 and 2003) and road transport has been the major source attributed to over $90 \%$ of the AQMAs declared by UK Local Authorities [21]. However, the increased kilometres travelled have been accompanied by enhanced vehicle abatement technology and other measures, which have assisted in preventing further air quality deterioration. Smaller and cleaner engine size is encouraged through incentives, and vehicles must meet the relevant EU emissions standard. In the UK, regulations are frequently updated to remain up to date with EU directives on vehicle emissions and testing at annual inspections (known as 'MOT's), to ensure that vehicles are maintained and meet required standards.

\section{Conclusion}

Despite the benefits of low population density and wind, air quality in New Zealand can be poor in urban centres. High vehicle ownership rates, insufficient regulation of fuel quality and vehicle emissions, and significant domestic emissions are culminating in exceedences of the National Standards. These air quality problems are intensified in Auckland, where approximately one third of New Zealand's population live.

The Local Air Quality Management review and assessment process was introduced to the UK under the Environment Act 1995 and subsequent National Air Quality Strategy giving local authorities new powers and obligations, requiring regular assessment of local air quality and integration of air quality management solutions into local policy. This shift was similar to the introduction of the RMA in New Zealand from a technology based approach for controlling emissions to an effects based process for managing ambient air quality. The UK requirements for carrying out monitoring and declaring AQMAs at a local level have been mirrored in the NES by New Zealand, however the production and implementation of action plans is not compulsory..

Although New Zealand has followed similar local air quality management process to the UK, the Auckland emissions inventory suggests that the biggest improvements can still be gained through reductions in transport and domestic emissions. The application of other initiatives implemented in Europe and the UK, such as smoke control areas, and stricter EU emission standards on vehicles, would help to greatly improve air quality in Auckland and across the country.

\section{Acknowledgements}

The authors would like to thank Janet Petersen and Xenia Meier from the Auckland Regional Council, for their input. 


\section{References}

[1] Statistics New Zealand; 2006 Census of Populations and Regions, Regional summary tables by regional council, http:/www.stats.govt.nz/ census/2006-census-data/regional-summary-tables.htm, 22 January 2006.

[2] Central Intelligence Agency; The World Factbook. Available at: https:/www.cia.gov/cia/publications/factbook/geos/nz.html, 22 January 2007.

[3] Ministry for the Environment; State of New Zealand's Environment 1997. Ministry for the Environment, Wellington, 1997.

[4] Map of New Zealand. Available at: http://www.allembassies.com/ new_zealand.html. 22 January 2007.

[5] Frieder, J.; Approaching Sustainability: Integrated Environmental Management and New Zealand's Resource Management Act. Ian Axford (New Zealand) Fellowships in Public Policy, Wellington, 1997. Available at: www.fulbright.org.nz/voices/axford/docs/friederj.pdf.

[6] New Zealand Government; Resource Management Act 1991. New Zealand Government, Wellington, 1991.

[7] J.W.S. Longhurst, C.I. Beattie, T.J. Chatterton, E.T. Hayes, N.S. Leksmono and N.K. Woodfield, Local air quality management as a risk management process: Assessing, managing and remediating the risk of exceeding an air quality objective in Great Britain. ARTICLE Environment International, Volume 32, Issue 8, December 2006, Pages 934-947.

[8] New Zealand Government; Resource Management (National Environmental Standards Relating to Certain Air Pollutants, Dioxins, and Other Toxics) Regulations 2004 (Including Amendments 2005) SR 2005/214. Ministry for the Environment. Wellington, 2005.

[9] Ministry for the Environment; Updated Users Guide to Resource Management (National Environmental Standards Relating to Certain Air Pollutants, Dioxins and Other Toxics) Regulations 2004 (Including Amendments 2005). Ministry for the Environment. Wellington, 2005.

[10] Auckland Regional Council; Auckland Air Emissions Inventory: 2004, Technical Publication 292. Auckland Regional Council. Auckland, 2006. Available at: http://www.arc.govt.nz/arc/environment/air

[11] Auckland Regional Council; The Ambient Air Quality Monitoring Network in the Auckland Region. Auckland Regional Council. Auckland, 2006.

[12] Greater London Authority; London Atmospheric Emissions Inventory 2002 Report. Greater London Authority. London 2005.

[13] Auckland Regional Council; A Day in the Life of the Auckland Region, Communities in Partnership with the Auckland Regional Council. Auckland Regional Council, Auckland, 2003.

[14] Land Transport New Zealand; New Zealand Motor Vehicle Statistics 2005. Land Transport New Zealand. Palmerston North, 2006. 
[15] Statistics New Zealand; 2006 Census. Available at: http:/www.stats.govt.nz/NR/rdonlyres/19D6A4B9-7D98-4AF9-970D5BBD139794CA/0/RegionalSummaryTablesRegionalCouncil.xls.

[16] Department for Transport; Transport Trends 2005 edition. Department for Transport. London, 2006.

[17] Ministry for the Environment; Gentle Footprints Boots 'N' All. Ministry of the Environment. Wellington, 2006.

[18] Ministry of Transport; The New Zealand Vehicle Emissions Screening Programme Resource Document. Ministry of Transport. Wellington, 2004.

[19] Ministry of Transport; Dealing with the Harmful Effects of Vehicle Emissions. Available at: http:/www.mot.govt.nz/jt-sp-index/.

[20] Auckland Regional Council; Auckland Regional Land Transport Strategy 2005. Auckland Regional Council. Auckland, 2005.

[21] T.J. Chatterton, E.T. Hayes, J.W.S. Longhurst; Managing Air Quality Are We Doing Enough? Air Pollution XIV, ed. Longhurst, J.W.S. \& Brebbia C.A., WIT Press: Southampton, Wessex pp 155-164. 